\title{
PERANCANGAN ALAT PEMINDAH PERAHU "MODEL DEREK" UNTUK NELAYAN TRADISIONAL PESISIR PANTAI CURAM
}

\author{
I GNK Yudhyadi' ${ }^{1)}$, I Made Suartika ${ }^{2)}$, Ahmad Zainuri $^{3)}$, M. Fajar ${ }^{4)}$ \\ ${ }^{1}$ Fakultas Teknik, Universitas Mataram \\ email: - \\ ${ }^{2}$ Fakultas Teknik, Universitas Mataram \\ email:wedhnda@yahoo.co.id \\ 3 Fakultas Teknik, Universitas Mataram \\ email: - \\ 4 Fakultas Teknik, Universitas Mataram \\ email: -
}

\begin{abstract}
The steep coastal topography makes the traditional fisherman facing a difficulty for moving boat from/to the sea towards the mainland. With the slope of 2 - 3 meters, it required at least 4 people do the job. This situation is very disturbing and reducing the productivity of the fishermen itself. Therefore, it needs a special equipment or appropriate technology to overcomes the drawback situation. So that, it will improve the efficiency and effectiveness of fishing operations. The method used in this study is an applied research method which the tool is designed based on real phenomena. Moreover, the outcome is the design of boat transfer device that will be used as an additional supplement to the teaching material of design and product development, industrial management, as well as a scientific publications. The design expected can improve the steep coastal fishermen productivity and welfare.
\end{abstract}

Keywords: boat transfer device , traditional fishermanl, productivity

\section{PENDAhULUAN}

Dengan panjang pantai lebih dari $81.000 \mathrm{~km}$ dan memiliki 17.504 pulau-pulau kecil (depdagri, 2006) potensi Kelautan Indonesia memberikan sumbangan devisa sebesar US \$2,6 milliar. Sebagai negara kepulauan, Indonesia merupakan negara kaya akan hasil laut. Hasil laut yang berlimpah seharusnya bisa menjadikan Indonesia sebagai negara kaya. Mengingat masih rendahnya teknologi dan sumber daya manusia dalam eksplorasi hasil laut yang ada, maka tidak mengherankan jika masyarakat pesisir pantai yang taraf hidupnya menengah kebawah atau dihimpit kemiskinan.

Problema kemiskinan masyarakat pesisir ("khususnya nelayan tradisional") disebabkan berbagai macam faktor. Misalnya; minimnya peralatan, mahalnya harga bahan bakar/BBM serta biaya-biaya operasional untuk membantu memindahkan perahu ke dalam/luar laut. Khususnya, untuk keadaan pesisir pantai yang curam membuat sebagian besar pendapatan nelayan digunakan untuk menutupi biaya-biaya pemindahan perahu. Banyak program yang diluncurkan oleh pemerintah atau lewat BRR, LSM, dan lembaga lain tetapi program tersebut baru merupakan target proyek dan tidak sepenuhnya memberi manfaat bagi masyarakat nelayan.

Pembangunan daerah pesisir kelautan masih di posisikan sebagai sektor pinggiran dalam pembangunan ekonomi nasional. Dengan posisi semacam ini bidang kelautan yang didefinisikan sebagai sektor perikanan, pariwisata bahari, pertambangan laut, industri maritim, perhubungan laut, bangunan kelautan, dan jasa kelautan serta masyarakat pesisir bukan menjadi arus utama dalam kebijakan pembangunan ekonomi nasional. Kondisi ini menjadi sangat ironis (bertolak belakang) mengingat 70\% wilayah Indonesia merupakan lautan dengan potensi ekonomi yang sangat besar. Apalagi dengan posisi geopolitis yang penting yakni lautan pasifik dan lautan hindia - kawasan paling dinamis dalam percaturan dunia baik secara ekonomi dan politik. Sehingga secara ekonomis dan politis sangat logis jika bidang kelautan dan masyarakat pasisir dijadikan tumpuan dalam pembangunan ekonomi nasional (Razak Miraza, 2009).

Menyebut "Nelayan" khususnya nelayan tradisional, orang akan selalu menghubungkannya dengan kehidupan yang serba susah, hidup pas-pasan, kondisi ini menggambarkan betapa miskinnya kehidupan nelayan tradisional. Secara realitas, memang kondisi kehidupan nelayan 
khususnya nelayan tradisional memang memprihatinkan. Padahal potensi pesisir dan laut begitu besar dimana laut Indonesia termasuk yang paling luas di dunia (Rokhmin, 2004).

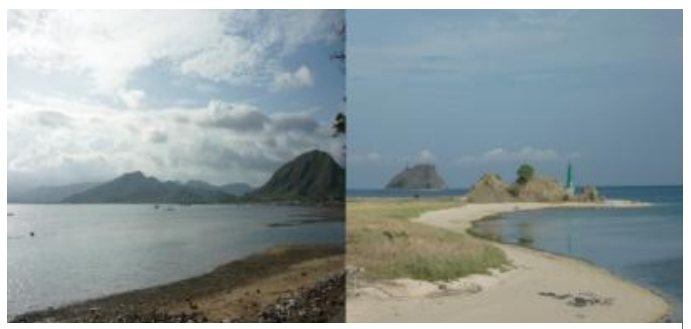

Gambar 2.1 Potensi dan View

Kepulauan Lombok

Salah satu contoh masyarakat pesisir yang berprofesi sebagai nelayan di pulau lombok NTB yang menjadi sumber informasi peneliti bahwa benar inilah kondisi yang di alami nelayan pesisir pantai. Nelayan mengeluhkan banyak hal dalam melakukan aktifitasnya sebagai nelayan, antara lain; mahalnya alat-alat penangkap ikan, harga BBM, serta susahnya melakukan kegiatan produksi secara individu yang mengakibatkan tidak efektif dan efisiennya kegiatan produksi nelayan. Kondisi tersebut akan mempengaruhi tingkat produktivitas dan kehidupan masyarakat pesisir.

Kondisi ini berdasarkan hasil observasi sementara terhadap beberapa daerah pesisir di pulau Lombok oleh calon peneliti bahwa sebagian besar ("bila tidak kita sebut semuanya") nelayan taraf kehidupannya masih rendah atau secara produktivitas sangat rendah. Bahkan, jika dihitung secara produktivitas ada nelayan yang produktivitas minus terutama nelayan di pesisir pantai yang curam. Minusnya produktivitas ini akibat tidak efektif dan efisiennya proses penambatan perahu baik sebelum maupun sesudah beroperasi.

Tidak efektif dan efisiennya operasional nelayan pesisir pantai curam disebabkan oleh kondisi geografis antara permukaan air laut dan daratan yang mencapai ketinggian rata-rata 2 meter. Sehingga proses penambatan dan penurunan perahu membutuhkan tenaga dan energi yang banyak dan besar. Banyaknya tenaga maupun besarnya energi yang dibutuhkan dalam operasional ini akan berpengaruh terhadap besarnya biaya-biaya yang timbul dan tentunya akan berpengaruh pula terhadap produktivitas total nelayan.

Karena itu perlu dicarikan solusi yang terbaik sebagai bentuk kepedulian terhadap ketidakberdayaan nelayan dalam rangka optimalisasi produksi. Melihat beberapa kendala dan upaya yang disebutkan sebelumnya maka perlu dibuatkan alat angkat sederhana untuk mempermudah operasionalisasi nelayan khususnya di daerah pesisir yang pantainya curam. Oleh sebab itu dalam penelitian ini dilakukan perancangan alat pemindah perahu yang dapat meningkatkan efektifitas dan efisiensi operasional nelayan.

\section{KAJIAN LITERATUR}

Potensi pesisir pantai hingga saat ini biasanya digunakan oleh pemerintah untuk menopang pendapatan daerah adalah sebagai objek pariwisata, penambangan, dan untuk masyarakat pesisir biasanya dimanfaatkan untuk penangkapan ikan dan transportasi antar pulau.

Kendala yang dialami oleh para nelayan selain minimnya peralatan biasanya kondisi geografis dari pantai tempat mereka menambatkan perahunya ada bentuk pantai yang curam dan pantai yang tidak curam. Dalam kondisi pantai yang curam, biasanya nelayan mengalami kesulitan menambatkan perahu karena bentuk pantainya yang curam. Seperti tampak dalam gambar 2.2, untuk menambatkan perahu nelayan membutuhkan tenaga yang banyak dan biaya yang banyak pula.

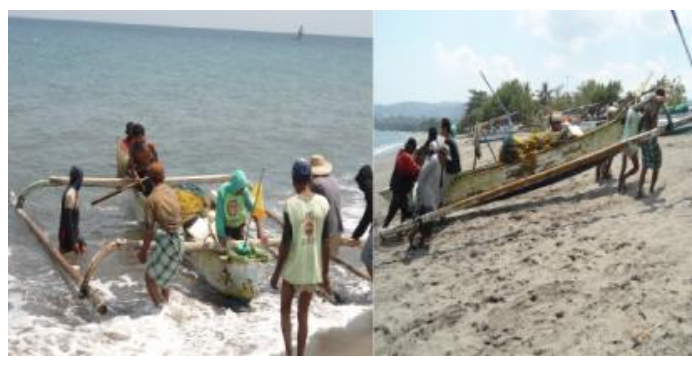

Gambar 2.2 Topografi Pantai Yang Curam

\section{METODE PENELITIAN}




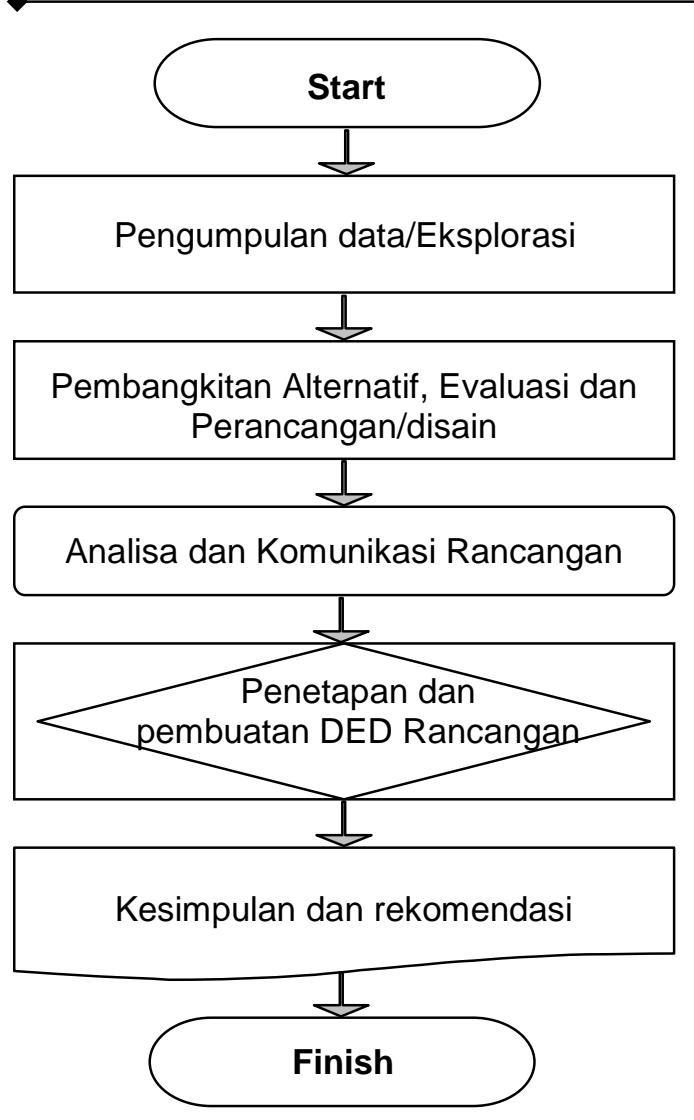

Gambar 3.1 Flow chart penelitian

Metode penelitian yang digunakan adalah metode konklusif deskriptif dengan studi kasus terhadap nelayan di pesisir pantai curam pulau Lombok. Untuk mendapatkan data dalam penelitian ini digunakan metode pengukuran lapangan, wawancara dan pendapat ahli sesuai alur penelitian gambar 3.1.

\section{HASIL DAN PEMBAHASAN}

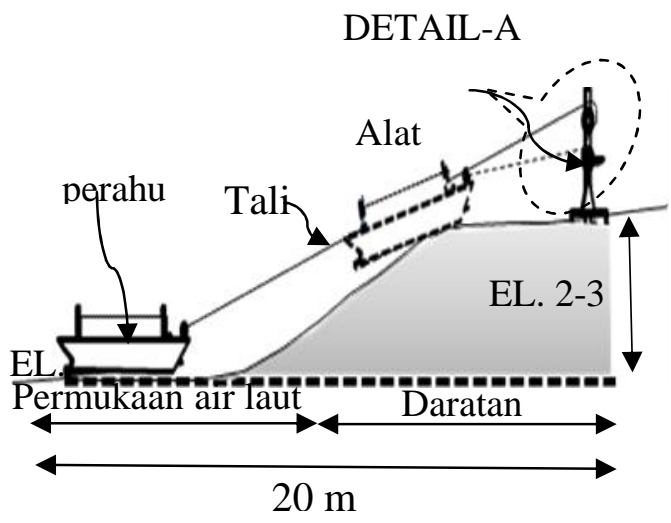

Gambar 4.2 Konseptual

Berdasarkan topografi seperti ditunjukkan pada gambar 4.1 maka dapat dirancang sebuah alat pemindah perahu model derek seperti gambar 4.2 dengan komponen utama yaitu; komponen penarik gambar 4.2 dan komponen dudukan alat gambar 4.3 .

\section{KESIMPULAN}

Berdasarkan detail komponenkomponen alat yang kemudian dilakukan perhitungan maka dapat ditarik kesimpulan mengenai ukuran-ukuran elemen mesin yang akan direncanakan dan bahan yang digunakan yaitu:

\section{Poros penggerak}

- Diameter poros $\left(d_{\mathrm{s}}\right)=30 \mathrm{~mm}$

- Bahan poros dipilih S30C, batang baja yang difinis dingin

- Perlakuan panas: dicelup dingin dan ditemper

- Ukuran alur pasak $8 \mathrm{~mm} \times 7 \mathrm{~mm} \times$ jari - jari fillet 0,25 $\mathrm{mm}$ (b $\times \mathrm{h} \times \mathrm{r}$ fillet)

- Panjang pasak yang aktif $\left(l_{k}\right)=32,04$ $\mathrm{mm}$

- Bahan pasak : S35C-D, dicelup dingin dan ditemper

2. Poros yang digerakkan

- Diameter poros $\left(d_{s}\right)=45 \mathrm{~mm}$

- Bahan poros dipilih S35C-D, batang baja yang difinis dingin

- Perlakuan panas: dicelup dingin dan ditemper

- Ukuran alur pasak $14 \mathrm{~mm} \times 9 \mathrm{~mm} \times$ jari - jari fillet 0,40 $\mathrm{mm}$ ( $b \times \mathrm{h} \times \mathrm{r}$ fillet)

- Panjang pasak yang aktif $\left(I_{k}\right)=103,51$ $\mathrm{mm}$

- Bahan pasak : S35C-D, dicelup dingin dan ditemper

- Dengan diameter Drum $=300 \mathrm{~mm}$

\section{Pulley dan V belt}

- Sabuk yang digunakan adalah type A dengan No 103 dan panjang $(L)=$ $2616 \mathrm{~mm}$

- Jumlah sabuk $(M)=1$ buah

- Jarak sumbu poros $(C)=1030,665 \mathrm{~mm}$

- $C_{t}=20 \mathrm{~mm}$, (penyetelan ke sebelah dalam dari letak standar)

- $\mathrm{C}_{\mathrm{t}}=40 \mathrm{~mm}$, (penyetelan ke sebelah luar dari letak standar)

- Diameter pulley :

1. Diameter nominal pulley penggerak $\left(d_{p}\right)=95 \mathrm{~mm}$

2. Diameter dalam pulley penggerak $\left(d_{d}\right)=87 \mathrm{~mm}$

3. Dimeter nominal pulley yang digerakkan $\left(D_{p}\right)=427,5 \mathrm{~mm}$

4. Diameter luar pulley penggerak $\left(d_{k}\right)$ $=104 \mathrm{~mm}$

5. Diameter dalam pulley yang digerakkan $\left(D_{d}\right): 419.5 \mathrm{~mm}$ 
6. Diameter luar pulley yang digerakkan $\left(D_{k}\right)=436,5 \mathrm{~mm}$

7. Diameter naf pulley yang digerakkan $\left(d_{B}\right)=80 \mathrm{~mm}$

8. Tebal pulley $(\mathrm{t})=17,5 \mathrm{~mm}$

\section{Bantalan pada poros}

Berdasarkan bentuk poros yang memerlukan gesekan yang sangat kecil, maka direncanakan bantalan gelinding bola radial alur dalam baris tunggal dengan bahan plat baja tahan karat, dengan spesifikasi sebagai berikut:

- Pada poros Penggerak

a. Nomor bantalan : 6006

b. Diameter dalam (d):30 $\mathrm{mm}$

c. Diameter luar $(D): 55 \mathrm{~mm}$

d. Lebar $(B): 13 \mathrm{~mm}$

e. Jari-jari $(r): 1,5 \mathrm{~mm}$

f. Kapasitas nominal dinamis spesifik $(C)$ $=1030 \mathrm{~kg}$

g. Kapasitas nominal statis spesifik $\left(C_{o}\right)=$ $740 \mathrm{~kg}$

h. Dengan umur nominal $L_{h}=62875,75$ jam

- Pada poros yang digerakkan :

a. Nomor bantalan : 6009

b. Diameter dalam (d): $45 \mathrm{~mm}$

c. Diameter luar $(D): 75 \mathrm{~mm}$

d. Lebar $(B): 16 \mathrm{~mm}$

e. Jari-jari $(r): 1,5 \mathrm{~mm}$

f. Kapasitas nominal dinamis spesifik $(C)$ $=1640 \mathrm{~kg}$

g. Kapasitas nominal statis spesifik $\left(C_{o}\right)=$ $1320 \mathrm{~kg}$

h. dengan umur nominal $L_{h}=7382824$ jam

5. Tali penarik

- Breaking Strength $=24,4 \mathrm{kN}$

- Safe Load $=4,89$ kN

\section{REFERENSI}

[1] Alimudin, "Pengelolaan sumberdaya perikanan tangkap yang berkelanjutan dan dampaknya terhadap kesejahteraan nelayan", Tugas Akhir, ITS, Surabaya.

[2] Arman N, 2000, "Perencanaan dan Pengendalian Produksi”, Guna Widya, Jakarta.

[3] Cranyonpedia.org, "Jenis-Jenis Pesawat Sederhana"

[4] Diana, A, 2001 " Total Quality Management (TQM)", Andi, Yogyakarta.

[5] Endarmadi Aji Prayitno, "Perencanaan alat tangkap dan permesinan kapal ikan type purse seine yang optimal", Tugas Akhir, ITS, Surabaya.

[6] Prakoso B, 2009, "Teknologi Informasi Untuk Kelautan Indonesia", LIPI, Indonesia

[7] Razak Miraza, 2009, "Implementasi Program Pemberdayaan Ekonomi Masyarakat Pesisir (PEMP) Di Kecamatan Tanjung Pura Kabupaten Langkat", Tugas Akhir, Universitas Sumatra Utara, Sumatra Utara. 